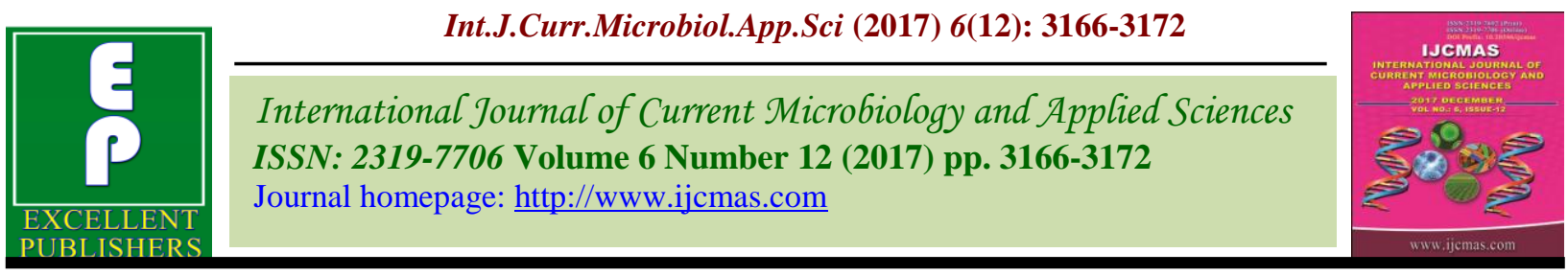

Original Research Article

https://doi.org/10.20546/ijcmas.2017.612.370

\title{
Study of Life Compatibility and Growth of Selected Ornamental Fishes under Aquarium in Sanjay Gandhi Biological Park
}

\author{
Anita Kumari ${ }^{1 *}$, Santosh Kumar ${ }^{2}$ and Ashok Kumar ${ }^{3}$ \\ ${ }^{1}$ Department of Education, Patna Women's College, Patna, Bihar-800001, India \\ ${ }^{2}$ Patna University, Patna, Bihar-800005, India \\ ${ }^{3}$ Bihar Agriculture University, Sabour, Bhagalpur, Bihar-813210, India \\ *Corresponding author
}

Ke y w or d s
$\begin{aligned} & \text { Trichogaster Leeri, } \\ & \text { Pterophyllum Scalare, } \\ & \text { Poecillia Latipinna, } \\ & \text { PGF, SGR. }\end{aligned}$
Article Info
$\begin{aligned} & \text { Accepted: } \\ & 23 \text { October } 2017 \\ & \text { Available Online: } \\ & 10 \text { December } 2017\end{aligned}$

\section{Keywords}

Poecillia Latipinna, PGF, SGR.

Article Info

Available Online:

10 December 2017

\section{A B S T R A C T}

Ornamental fish keeping is a popular, easy and stress relieving hobby and enterprise. A study was conducted to examine the effects of environment and different diets on growth performance of aquarium fishes like Pearl Gourami (Trichogaster leeri), Angle (Pterophyllum scalare), Molly (Poecillia latipinna) and Gold (Carassius auratus). Twenty five sample of each fish were fed with three different diets like live earth worm (LEW), mixed feed and prepared granulated feed (PGF). All fishes were cultured at environment having $\mathrm{pH}$ range of 6-8 and temperature from $22-28^{\circ} \mathrm{C}$. The selected fishes were fed with different types of feed twice in a day for 45 days and their performances in terms of growth and survival were determined. It was found that the parameters like length gain, weight gain and specific growth rate was higher in fishes fed with mixed feed, followed by live earth worm (LEW) and prepared granulated feed (PGF). Survival rate was also higher in fishes fed with mixed feed, followed by live earth worm (LEW) and prepared granulated feed (PGF). It is observed that desirable growth and survival might not be achieved with same feed in Angle Molly and Gold fishes.

\section{Introduction}

Ornamental fishes are attractive and colorful species which can be kept as pets in confined spaces like aquarium or garden pool with the purpose of enjoying their beauty. Keeping ornamental fish has become popular as an easy and stress relieving hobby and has emerged as one of the most popular hobbies in the world. The ever-increasing demand for ornamental fishes has made them an important component of global fish trade. Ninety percent of the world's trade volume concentrates around tropical freshwater fishes of which majority is contributed by diverse wild-caught species. Wide collection of freshwater fishes for the aquarium trade has been considered as an arguable issue (Raghavan et al., 2013). Considering the enormous and diverse indigenous fish resources of the country, there is immense scope for India to become a potential candidate and a strong competitor in the international ornamental fish trade. The popularity of ornamental fish varieties as aquarium species both in domestic as well as in the international markets has already been documented (Gupta et. al., 2016). India's contribution to the world trade in ornamental fish is an insignificant at around $1 \%$. The total 
Value of ornamental fish exported stands at about Rs. 30 million, although the potential is very high. India exported 11, 34,948 MT of seafood worth an all-time high of Rs 37, 870.90 crore in 2016-17. About 80\% of ornamental fishes from India are exported to international market, whose major share comes from the all regions of country, which is endowed with diverse natural water bodies with an abundance (250 species) of ornamental fishes. However, there is vast unexplored potential for production of indigenous ornamental fishes and promoting aquarium keeping in India. The present work was carried out to assemble some comparative data of selected ornamental fishes with main objective to assess their life compatibility and rate of growth after feeding under Aquarium Environment.

\section{Materials and Methods}

\section{Experimental location}

A study was conducted for different ornamental fishes like Pearl Gourami, Anglefish, Molly and Gold available at Sanjay Gandhi biological park, Patna, Bihar in the year 2013-14. The experimental site is located at $25.5974^{\circ} \mathrm{N}$ latitude and $85.1003^{\circ}$ E longitude in Bihar. This park comprising a biological park with a zoo which has an area of 61.90 ha. As per climate of this location is concern, the cold weather commences early in November and comes to an end in the middle of March. The minimum and maximum temperatures at the location in the winter are varied from $08-20{ }^{0} \mathrm{C}$ and $21-35{ }^{0} \mathrm{C}$ respectively. The summer starts from March and lasts until the middle of June. The highest temperature is often registered in May and June varies from $32-41{ }^{\circ} \mathrm{C}$ which are the hottest months in the state. The commencement of monsoon may be as early as the last week of June or as the first or second week of July.

\section{Feeding and sample analysis}

Sampling was conducted during early morning between 06:00-08:00 hrs involving the zoo's staff men. After collection, 25 fishes of each randomly selected were segregated according to their family. The fresh specimens were photographed and few representative species from each family were preserved in $10 \%$ formalin for identification, while others were released in their habitat. The collected specimens were subsequently identified following standard books on fish taxonomy (Jayaram, 1999). Fishes were categorized as per Ghosh et al., (2003). Mixed feed, living earth worm (LEW), and prepared granulated feed (PGF) were selected as feed and fed to each fish twice a day for 45 days. Each treatment was performed in triplicate. The selected live feed organisms were cultured in 150 liters at $18-30{ }^{\circ} \mathrm{C}$ temperature and $\mathrm{pH}$ of 6-8 $( \pm 0.11)$ of filtered water (Sumithra et al., 2014). Fish from each replicate were measured at the beginning and every 10 days until the end of experiment.

Wet weight was determined with an electronic balance (0.01 g precision) and length was measured with digital vernier calliper (0.01 precision). Simultaneously mean weight gained, mean length gained and specific growth rate (SGR) were calculated by following formula (Mohideen, 2014):

Mean Weight Gain $(\mathrm{MWG})=$ Mean final body weight - Mean initial body weight (i)

Mean Length Gain (MLG) = Mean final body length - Mean initial body length (ii)

Specific Growth Rate $(\mathrm{SGR})=\left(\ln \mathrm{W}_{t}-\ln \mathrm{W}_{0}\right)$ $\times 100 \mathrm{t}^{-1}$ (iii)

Survival rate $=\frac{\mathrm{N}_{\mathrm{t}}}{\mathrm{N}_{0}} \times 100$ 
Where $\ln$ is natural logarithm; $\mathrm{W}_{t}$ and $\mathrm{W}_{0}$ were final and initial fish weights (g), respectively, and $\mathrm{t}$ is time (days) between $\mathrm{ln}$ $\mathrm{W}_{t}$ and $\ln \mathrm{W}_{0} . \mathrm{N}_{\mathrm{t}}$ and $\mathrm{N}_{0}$ were final and initial numbers of fish in each replicate, respectively.

\section{Results and Discussion}

During the study it was found that all the selected fishes (Table 1) from the Kingdom: Animalia, Phylum: Chordata and Class: Actinopterygii. The water level in the culture medium should be reduced to $20 \mathrm{~cm}$ during spawning and the temperature should be approximately $28{ }^{\circ} \mathrm{C}$ and with a pH of around 7. After spawning both adults cannot be kept together. The eggs hatch after two days and the fry become free swimming three days later. The temperature needs to be high $28^{\circ} \mathrm{C}$ and with little or no water movement. Since they are air breathers, filtration is not necessary (Morshuizen, 2007). Angel fishes were kept in a warm aquarium, ideally around $27{ }^{\circ} \mathrm{C}$ and with a $\mathrm{pH}$ ranges from 6 to 7.5. They will lay the eggs on a vertical or diagonal surface. Mollies are tropical fish so that means we need an aquarium heater. The water temperature should be between 28 to 30 ${ }^{\circ} \mathrm{C}$. Females can reach a size of up to $6.3 \mathrm{~cm}$ whereas the males usually get to be about 3.8 $\mathrm{cm}$ inches. Breeding them is fairly easy since they are livebearers. They can cop up with the environment having $\mathrm{pH}$ ranges from 7 to 8 and temperature 18 to $26^{\circ} \mathrm{C}$. Gold fishes were also recorded for temperature were in the range of $24-28^{\circ} \mathrm{C}$, dissolved oxygen from 5.00 to $6.23 \mathrm{mg} / \mathrm{L}$, and $\mathrm{pH}$ from 7.71 to 7.89 . Water quality parameters were maintained within the acceptable ranges for goldfish (Gumus, 2016).

\section{Effect of feed on growth}

In the present study, results indicated (Fig. 1) enhanced growth performance after fed with mixed feed. From Figure 1, it was observed that mean weight gained by Pearl Gourami, Angel, Molly and Gold was 5.29, 3.32, 0.13 and $2.8 \mathrm{~g}$ respectively. This could be due to the high crude protein content, feed acceptability and palatability, improved food intake and other factors which are responsible for higher growth rate and survival. Similar results of higher growth performance of fish fed with mixed feed have been reported earlier by Sumithra (2014). Shim and Bajrai (1962) reported that $70 \%$ crude protein was found to be suitable food for the fry of Poecilia reticulata. Dahlgren (1979) also reported that the guppy, Poecilia reticulata being omnivorous requires around $40 \%$ dietary protein. As per Figure 1 it was found that lower growth performance of 2.07, 0.85 and $2.54 \mathrm{~g}$ was observed for Angle, Molly and gold fishes fed with living earth worm (LEW). Many hypotheses have been put forth to explain about the low performance of LEW as food for fishes. From Table 2-4, mixed fixed feed proved to be a better feed than individual live feed for gaining length and weight and for attaining high specific growth rate. Fishes fed with PGF and LEW shows less length and weight gain, specific growth rate and survival rate than mixed feed (Fig. 1). This could be due to its thick shell, unsuitable movement and low nutritional value than that of the others feeds.

As reported in many edible and ornamental fishes present study also indicated that live feed is inevitable for the rearing of early developmental stages of mollies. Based on the present study, it is suggested that for high growth and survival of Pear Gourami is possible by providing mixed feed and in some extend PGF for their rearing in aquarium. These results were inlined with reports of James (2004) for feed requirement of ornamentals fishes; Ahilan and Kumaran (2003) for gold fish and Degani (1993) reported supplementation of diets with Artemia increased growth of juvenile angelfish. 
Table.1 Details of selected ornamental fishes at Sanjay Gandhi biological park during the study

\begin{tabular}{|l|c|l|l|c|c|c|c|}
\hline $\begin{array}{l}\text { S. } \\
\text { No }\end{array}$ & Common & \multicolumn{1}{|c|}{ Scientific } & \multicolumn{1}{|c|}{ Order } & $\begin{array}{c}\text { Size, } \\
\mathbf{c m}\end{array}$ & $\mathbf{p H}$ & $\begin{array}{c}\text { Temperature, } \\
{ }^{\circ} \mathbf{C}\end{array}$ & $\begin{array}{c}\text { Life, } \\
\text { Yr }\end{array}$ \\
\hline 1. & $\begin{array}{c}\text { Pearl } \\
\text { Gourami }\end{array}$ & $\begin{array}{l}\text { Trichogaster } \\
\text { leeri }\end{array}$ & Perciformes & 12 & 7 & $22-28$ & $5-8$ \\
\hline 2. & Angel & $\begin{array}{l}\text { Pterophyllum } \\
\text { scalare }\end{array}$ & Perciformes & 15 & $6-7.5$ & 27 & $8-10$ \\
\hline 3. & Molly & $\begin{array}{l}\text { Poecillia } \\
\text { latipinna }\end{array}$ & Cprinodontiformes & $10-12$ & $7-8$ & $23-28$ & $3-5$ \\
\hline 4. & Gold & $\begin{array}{l}\text { Carassius } \\
\text { auratus }\end{array}$ & Cypriniformes & $10-12$ & $7-8$ & $24-28^{\circ} \mathrm{C}$ & $5-10$ \\
\hline
\end{tabular}

Table.2 Growth performance of selected fish fed with mixed feed in 45 days feeding trials

\begin{tabular}{|l|c|c|c|c|}
\hline \multicolumn{1}{|c|}{ Parameters } & Pearl Gourami & Angel & Molly & Gold \\
\hline Mean Initial weight, g & $1.51 \pm 0.02$ & $3.57 \pm 0.24$ & $0.04 \pm 0.0$ & $1.17 \pm 0.06$ \\
\hline Mean Final weight, g & $6.80 \pm 0.12$ & $6.89 \pm 0.41$ & $0.17 \pm 0.0$ & $3.97 \pm 0.11$ \\
\hline Mean Weight gain, g & $5.29 \pm 0.10$ & $3.32 \pm 0.17$ & $0.13 \pm 0.0$ & $2.8 \pm 0.05$ \\
\hline Mean Initial length, cm & $8 \pm 0.11$ & $4.12 \pm 0.14$ & $1.23 \pm 0.11$ & $0.8 \pm 0.03$ \\
\hline Mean Final length, cm & $12 \pm 0.19$ & $6.35 \pm 0.27$ & $2.67 \pm 0.21$ & $3.1 \pm 0.28$ \\
\hline Mean Length gain, cm & $4.0 \pm 0.08$ & $2.13 \pm 0.13$ & $1.44 \pm 0.10$ & $2.3 \pm 0.25$ \\
\hline $\begin{array}{l}\text { Specific growth rate } \\
\text { (SGR) (\%) }\end{array}$ & 3.34 & 1.46 & 3.2 & 2.71 \\
\hline Survival rate (\%) & 96 & 76 & 88 & 64 \\
\hline
\end{tabular}

Table.3 Growth performance of selected fish fed with prepared granulated feed (PGF) feed in 45 days feeding trials

\begin{tabular}{|l|c|c|c|c|}
\hline Parameters & $\begin{array}{c}\text { Pearl } \\
\text { Gourami }\end{array}$ & Angel & Molly & Gold \\
\hline Mean Initial weight, g & $1.42 \pm 0.03$ & $3.43 \pm 0.24$ & $1.05 \pm 0.0$ & $1.15 \pm 0.06$ \\
\hline Mean Final weight, g & $5.62 \pm 0.12$ & $5.92 \pm 0.32$ & $2.14 \pm 0.0$ & $3.62 \pm 0.11$ \\
\hline Mean Weight gain, g & $4.2 \pm 0.9$ & $2.49 \pm 0.08$ & $1.09 \pm 0.0$ & $2.47 \pm 0.05$ \\
\hline Mean Initial length, cm & $7 \pm 0.11$ & $3.09 \pm 0.14$ & $1.12 \pm 0.11$ & $1.9 \pm 0.28$ \\
\hline Mean Final length, cm & $10 \pm 0.19$ & $5.92 \pm 0.27$ & $2.08 \pm 0.21$ & $2.9 \pm 0.28$ \\
\hline Mean Length gain, cm & $3 \pm 0.08$ & $2.83 \pm 0.00$ & $0.96 \pm 0.00$ & $2.2 \pm 0.00$ \\
\hline $\begin{array}{l}\text { Specific growth rate } \\
\text { (SGR) (\%) }\end{array}$ & 3.05 & 1.21 & 1.58 & 2.54 \\
\hline Survival rate (\%) & 92 & 76 & 80 & 72 \\
\hline
\end{tabular}


Table.4 Growth performance of selected fish fed with living earth worm (LEW), feed in 45 days feeding trials

\begin{tabular}{|l|c|c|c|c|}
\hline \multicolumn{1}{|c|}{ Parameters } & $\begin{array}{c}\text { Pearl } \\
\text { Gourami }\end{array}$ & Angel & Molly & Gold \\
\hline Mean Initial weight, g & $1.43 \pm 0.01$ & $3.10 \pm 0.19$ & $1.3 \pm 0.0$ & $1.26 \pm 0.04$ \\
\hline Mean Final weight, g & $4.79 \pm 0.12$ & $5.17 \pm 0.21$ & $2.15 \pm 0.0$ & $3.8 \pm 0.12$ \\
\hline Mean Weight gain, g & $4.36 \pm 0.11$ & $2.07 \pm 02$ & $0.85 \pm 0.0$ & $2.54 \pm 08$ \\
\hline Mean Initial length, cm & $6.8 \pm 0.13$ & $3.12 \pm 0.12$ & $1.14 \pm 0.12$ & $0.68 \pm 0.02$ \\
\hline Mean Final length, cm & $9.5 \pm 0.17$ & $5.17 \pm 0.26$ & $2.01 \pm 0.19$ & $2.3 \pm 0.23$ \\
\hline Mean Length gain, cm & $2.7 \pm 0.14$ & $2.05 \pm 0.14$ & $0.87 \pm 0.07$ & $1.62 \pm 021$ \\
\hline $\begin{array}{l}\text { Specific growth rate } \\
\text { (SGR) (\%) }\end{array}$ & 2.6 & 1.13 & 1.11 & 2.45 \\
\hline Survival rate (\%) & 84 & 72 & 76 & 64 \\
\hline
\end{tabular}

Fig.1 Mean weight gain for the three diets evaluated (MF, PGF and LEW)

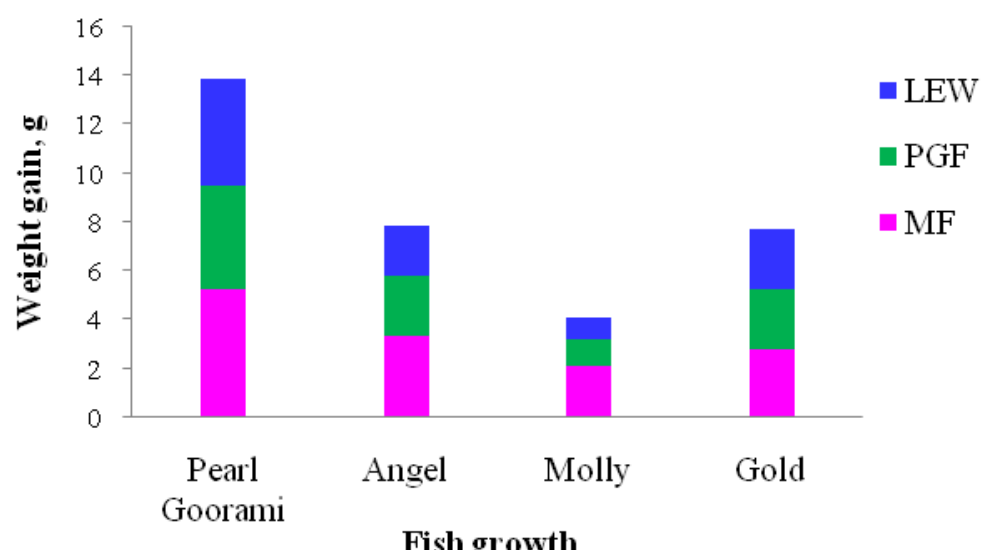

Fig.2 Specific growth rate (SGR, \%) based on feed in selected fishes

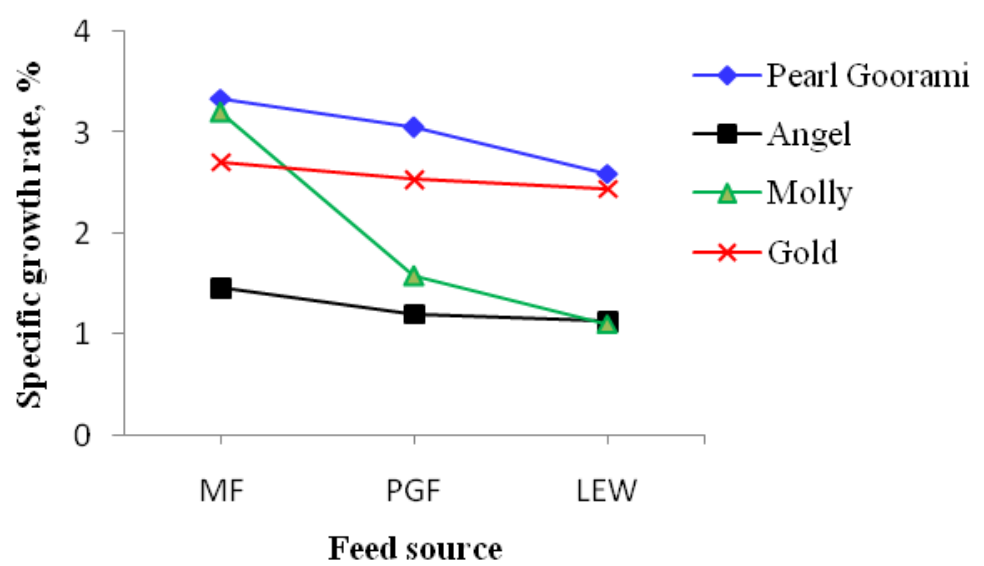


Fig.3 Survival rate (\%) based on feed in selected fishes

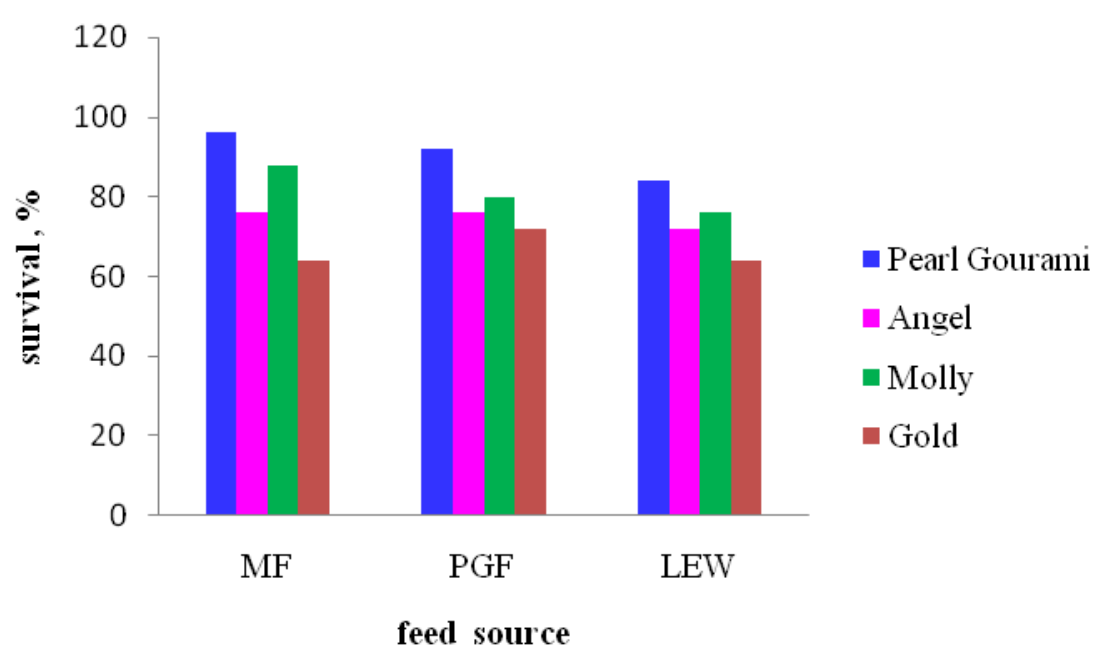

Hence, all these causes like uncontrolled environment and unavailability of nutritional feed and proper management may be responsible for the poor growth in fishes. It was also found that the SGR of the fish that fed with mixed feed ensured better growth rate in the Pearl Gourami compared to the other two feeds and fishes (Fig. 2). So based on result one can strongly emphasise that survival was also significantly affected by feed. Survival rate (Fig. 3) in Pearl Gourami, Angel, Molly and Gold was found to 96, 76, 88 and $64 \%$ respectively fed with mixed feed; 92, 76, 80 and $72 \%$ fed with PGF and 84, 72, 76 and $64 \%$ fed with LEW. Similar findings have been reported by Shim and Chua (1986).

Results of this study have shown that the fishes like Pearl Gourami, Anglefish, Molly and Gold reared at $\mathrm{pH}$ ranges 6-8 and water temperature of $22-28^{\circ} \mathrm{C}$ is best suitable for aquarium fishes. Growth performance and survival of Pearl Gourami can be accelerated by feeding with mixed feed as nutritional and commercial diet. Whereas living earth worm (LEW) and prepared granulated feed (PGF) is concerned, these were found to be less advantageous on fish growth. Hence based on study result it can be concluded that mixed feed of suitable sized might be more advantageous for length and weight gain, specific growth rate and survival of fishes available in the aquarium at controlled atmosphere. Nevertheless, earlier report also asserted that larval survival was greatest in diet which has a combination of mixed and extruded diet. However, detailed studies on the nutritional requirements of Pearl Gourami are essential for maximum growth and survival which will provide a range of nutrients to ensure consistent growth. This study has significance and implications in rearing of ornamental fish.

\section{References}

Ahilan B and R. Kumaran. (2003).Effect of live food organisms on the growth and gonadal maturation of gold fish (Carassius auratus). Indian Journal of Fisheries. 50(1):131-133.

Dahlgren B T (1979). Effects of population density on fecundity and fertility in the guppy, Poecilia reticulata (Peters). $J$. Fish Biol., 15: 71-91. 
Degani G, 1993. Growth and body Composition of juveniles of (Pterophyllum scalare) (Lichtenstein) (Pisces; Cichlidae) at different densities and diets. Aquac. Fish. Manage. 24:725-730.

Ghosh A, B K Mahapatra and N C Datta (2003). Ornamental fish farmingsuccessful small scale aqua business in India. Aquaculture Asia 8(3): 14-16.

Gumus E, Aydin B, and Kanyilmaz M (2016). Growth and feed utilization of goldfish (Carassius auratus) fed graded levels of brewers yeast (Saccharomyces cerevisiae). Iranian Journal of Fisheries Sciences 15(3):1124-1133.

Gupta S, Dubey S K, Trivedi, R K, Chand, B K 4 and Banerjee, $S$ (2016). Indigenous ornamental freshwater Ichthyofauna of the Sundarban Biosphere Reserve, India: status and Prospects. Journal of Threatened Taxa. 8(9): 9144-9154.

James R And Sampath K (2004). Effect of Feed type on growth and fertility in ornamental fish, Xiphophorus helleri. The Israeli Journal of Aquaculture. 56(4): 264- 273.

Jayaram, K C (1999). The Freshwater Fishes of the Indian Region. Narendra Publishing House, New Delhi, 551pp.
Mohideen A K S, Sheriff M A and Altaff K (2014). Effect of three different feeds on the growth and survival of sailfin molly Poecilia latipinna (Lesueur, 1821). Revelation and Science 4(1) 4548.

Raghavan R., Dahanukar D, Tlusty M, A.L. Rhyne A L, Kumar K K, Molur S and Rosser A M (2013). Uncovering an obscure trade: threatened freshwater fishes and the aquarium pet markets. Biological Conservation 164: 158-169.

Shim, K F and Y L Chua. (1986). Some studies on the protein requirement of the guppy, Poecilia reticulata (Peters). J. Aqua. Aquat. Sci., 4: 79-84.

Shim, K.F and Bajrai, J. (1982). Growth rates and food conversion in young guppy, Poecilia reticulate peters fed on artificial and natural foods Singapore, ornamental fish culture. Singapore Journal of Primary Industries, 10(1): 26-38.

Sumithra V, Janakiraman A, Altaff K (2014). Influence of Different Type of Feeds on Growth Performance in Black Molly, Poecilia sphenops. International Journal of Fisheries and Aquatic Studies, 1(6): 24-26.

\section{How to cite this article:}

Anita Kumari, Santosh Kumar and Ashok Kumar. 2017. Study of Life Compatibility and Growth of Selected Ornamental Fishes under Aquarium in Sanjay Gandhi Biological Park. Int.J.Curr.Microbiol.App.Sci. 6(12): 3166-3172. doi: https://doi.org/10.20546/ijcmas.2017.612.370 